Primljen / Received: 29.6.2009.

Ispravljen / Corrected: 29.12.2011.

Prihvaćen / Accepted: 8.6.2012.
Dostupno online / Available online: 16.7.2012.

\section{Hydrodynamic wave analysis as basis for sustainable beach design}

Authors:

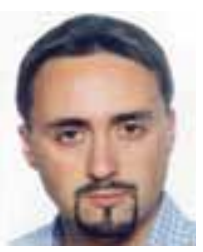

\section{Željan Pernat, Mijo Vranješ}

Professional paper

\section{Hydrodynamic wave analysis as basis for sustainable beach design}

The regulation and stabilization of movable parts of shoreline is a complex task, as the sea and shore interaction is quite complex is such coastal areas. If the analysis concerns beaches, either natural or newly built ones, the task becomes even more complex as they are used for rest and recreation, and so an appropriate maintenance must also be provided. Numerical modelling is conducted to enable proper shaping and maintenance of beaches. In this paper, the CGWAVE model is used to optimize a beach made of granular material, in order to ensure its sustainability.

Key words:

beaches, granular material, sustainability of beaches, numerical modelling

Stručni rad

\section{Željan Pernat, Mijo Vranješ}

\section{Hidrodinamička valna analiza - osnova za projektiranje održivih plaža}

Prof. Mijo Vranješ, PhD. CE

University of Split

Faculty of Civil Engineering, Arch. and Geodesy

mijo.vranjes@gradst.hr
Uređivanje i stabilizacija pomičnih dijelova obalne crte složena je zadaća jer je u takvim priobalnim područjima složena interakcija mora i obale. Ako se analiziraju plaže, bilo prirodne bilo novoizgradene, zadaća je još zahtjevnija budući da one služe za odmor i rekreaciju te je nužno i odgovarajuće održavanje. Za pravilno oblikovanje i održavanje plaža primjenjuje se numeričko modeliranje. U radu je primjenom modela CGWAVE provedena optimalizacija oblika plaže od zrnatih materijala u svrhu osiguranja njezine održivosti.

Ključne riječi:

plaže, zrnati materijal, održivost plaža, numeričko modeliranje

Fachbericht

\section{Željan Pernat, Mijo Vranješ}

\section{Hydrodynamische Wellenanalyse - Grundlage für die Projektierung von nachhaltigen Stränden}

Die Adaptierung und Stabilisierung von beweglichen Teilen der Küstenlinie ist eine komplizierte Aufgabe, weil in den Gebieten vor der Küste die Interaktion von Meer und Küste schwierig ist. Wenn die Strände analysiert werden, sei es natürliche oder neu ausgebaute, ist die Aufgabe noch anspruchsvoller, da sie zum Urlaub sowie zur Erholung dienen und die Instandhaltung notwendig und entsprechend ist. Für eine regelmäßige Gestaltung und Instandhaltung des Strandes wird eine numerische Modellierung angewandt. In der Arbeit wurde durch Anwendung des CGWAVE-Modells die Optimierung der Strandform aus körnigen Materialien zum Zwecke der Sicherstellung ihrer Nachhaltigkeit durchgeführt. 


\section{Introduction}

Previous practice in the design of beaches made of granular materials at the Croatian Adriatic coast has pointed to the need of conducting the hydrodynamic wave analysis by numerical modelling of wave agitation. Beach shaping and achieving beach stability is a very complex and highly sensitive task. The beach sustainability is primarily reflected in its ability to retain the existing (or artificially defined) configuration in terms of numerous effects of either natural or artificial nature. The wave activity exerts the biggest natural impact on sea beaches, and so a detailed knowledge of the wave field in the studied water zone is needed. This can only be obtained by detailed numerical wave agitation modelling, or by long-term field measurements. The possibility of using such an analytic procedure as the basis for designing sustainable beaches made of granular materials is presented in this paper on an example of the Hotel Split beach.

\section{Hydrodynamicmodellingofwaveagitation for designpurposes}

\subsection{Basic approach}

A basic approach or sequence of procedures that lead to a good-quality beach design solution using the wave agitation modelling is shown in Figure 1.

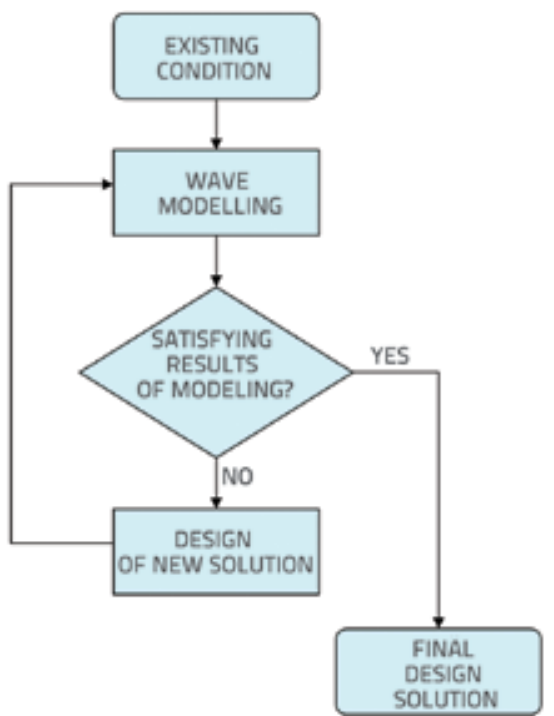

Figure 1. Sequence of hydrodynamic wave analysis procedures for the design of sustainable beaches

First, the wave agitation modelling is conducted for the existing coastline configuration and the corresponding results are analysed. Based on these results, the decision on the need to intervene in the beach water area is made. If results show that the intervention is needed, then a new solution is created. The wave agitation modelling is conducted once again for the new solution. The procedure is repeated until the results of the solution under study are satisfactory. These results then become the basis for a detailed elaboration of the final design solution.

\subsection{Basic wave agitation process equation of the applied numerical CGWAVE model}

The approximation of the coastal wave motion can be made using the basic shape of the mild slope equation [1, 2]:

$\nabla \cdot\left(C C_{g} \nabla_{\varphi}\right)+\omega^{2} \frac{C_{g}}{C} \varphi=0$

where $C$ is the wave velocity, $C_{q}$ the wave group velocity, $\phi(x, y)$ the complex two-dimensional potential, and $\omega$ is the angular frequency. The equation (1) is a two-dimensional elliptic partial differential equation that derives solutions of unknown potentials $\phi(x, y)$ in the horizontal plane. The equation (1) is valid for the mild $|\nabla D| / k D \ll 1$ ( $D$-depth, $k$-wavenumber) [3]. It includes all forms of wave transformations in coastal areas such as diffraction, refraction, shallow water effects, and reflection. In order to include nonlinear processes in the model, like wave refraction and friction at the bottom, the basic equation (1) has to be extended $[4,5]$ :

$\nabla \cdot\left(C C_{g} \nabla \varphi_{0}\right)+\left(\omega^{2} \frac{C_{g}}{C}+i C_{g} \omega W_{d}\right) \varphi_{0}=0$

where $W_{d}$ is the coefficient combining the effects of wave breaking and bottom friction [5].

Once the boundary conditions are set, the mild slope equation in the inner area of a model discretized by a triangular finite element grid [5] can be solved using the CGWAVE model [7]. The elliptic mild slope equation can be written as a matrix after the discretization. After the term modification, it can be written in the following formulation due to conditions that guarantee its convergence $[5,6]$ :

$\left[A^{*}\right][A]\{\phi\}=\left[A^{*}\right]\{f\}$

Where $[A]$ is the coefficient matrix; $\{\phi\}$ is an unknown vector of potential values in network nodes; $\{f\}$ the boundary conditions vector, and $\left[A^{*}\right]$ is the complex conjugated transposed matrix of the matrix $[A]$.

The equation is solved using an iterative method of conjugated gradients, and the solving algorithm implemented in the CGWAVE is given in literature $[5,7]$.

Once the solution is found for the potential $\phi_{1}$ various cinematic parameters for each node of the finite element grid can be calculated [5].

\subsection{Numerical wave agitation modelling procedure 2.3.1. Geodetic and Hydrographic Data}

The three-dimensional geodetic survey in textual (ASCII) format, and point coordinates $(x, y, z)$ defining the bottom 
bathymetry and coastal boundary, are required for creation of the model field. A realistic graphical environment, e.g. ortophoto surface (Figure 2), can also be entered in order to maintain visibility and regulate the area setting.

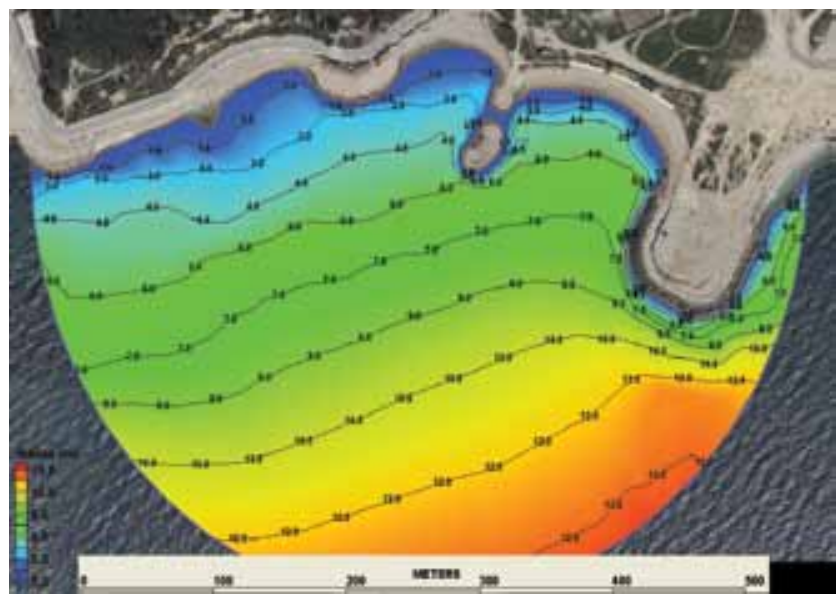

Figure 2. Existing state and bathymetry of local waters at the Hotel Split beach, ortophotographic view

According to the bottom bathymetry (Figure 2), the depths present an average slope of approximately 1:15, which is significantly less than the maximum slope for the mild slope equation $[4,5,8]$. Also, it is very important to have an appropriate knowledge of the sea level fluctuation statistics for the area under study. As no sea level measurements are available for the Hotel Split beach locality, the survey data collected in the period from 1995 to 2005 [2] at the Split tide gauge station, located at the City Port (Figure 3), will be used.

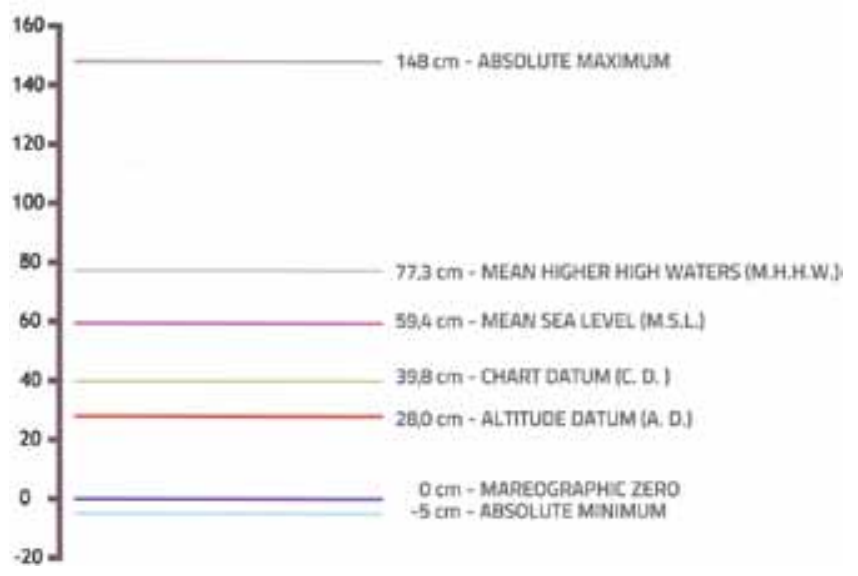

Figure 3. Typical relations compared to the tide gauge datum as registered at the Split tide gauge station, adapted from [9]

The mean sea level (MSL) will be used for all numerical wave agitation simulations, taking into account the fact that in case of stormy wind (Jugo) the sea level can rise by more than 0.50 $\mathrm{m}$ above the mean level.

\subsubsection{Wind-wave data}

As it is positioned within the Adriatic Seal (Fig. 4), the area of the hotel Split beach is a relatively well protected water area exposed to wind waves generated in the Brač and Split channels (III. and IV. quadrant waves)

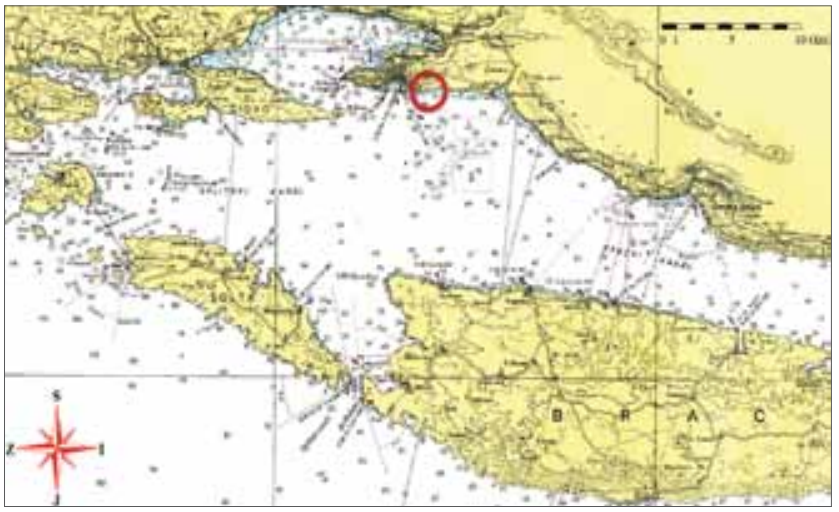

Figure 4. Wider water area of Hotel Split beach

Waves relevant for shaping the beach and shore profile are the waves generated by the following winds: SE-Jugo, SSW-Lebic and WSW-Maestral. The wind called Jugo, dominant in the winter period, generates powerful waves that carry most of the energy to the coastline throughout the year. In other words, Jugo exerts the most powerful effect and influence on the shape and sustainability of the beach. On the other hand, Lebic is fleeting and rare. It generates waves that destroy the beach by scattering the beach material. Maestral often blows in summer, which also contributes to the formation of sandy beaches, and affects their sustainability. Thus, the wave analysis must be conducted for this particular beach in two directions of incident waves (Jugo and Maestral), because these waves are the biggest contributors to its sustainability, as the beach can not be protected from waves generated by the Lebić wind.

Since the wave measurement data are not available for the area under study, deep-water wave parameters must be defined for water agitation simulations. These parameters imply deep-water wave spectra for incident wave directions based on wind measurements [10]. Many methods can be used to obtain these parameters (e.g. the Gröen-Dorrenstein method), and a number of wave forecasting methods are also available. Wave parameters that will be used in the analysis of the beach under study are given in the literature [11] for the five-year recurrence interval (Table 1).

When modelling wave agitation for these types of water areas that are often exposed to wind waves with main direction variations at the local level, and when wave terms are described by a power spectrum, it is necessary to take into account a certain directional dispersion around the basic direction of incident waves $[2,12]$. The directional 
dispersion of $25^{\circ}$ around the main directions of incident waves was selected in the case under study.

Table 1. Deep-water wave parameters

\begin{tabular}{|l|c|c|c|}
\hline Wave direction & $H_{s}[\mathrm{~m}]$ & $\mathrm{T}_{0}[\mathrm{~s}]$ & $\mathrm{T}_{\mathrm{p}}[\mathrm{s}]$ \\
\hline SE (southeast) & 2,9 & 6,3 & 7,6 \\
\hline WSW (west south west) & 1,2 & 4,1 & 4,9 \\
\hline $\begin{array}{l}\mathrm{H}_{\mathrm{s}}-\text { significant wave height } \\
\mathrm{T}_{0}-\text { mean wave period } \\
\mathrm{T}_{\mathrm{p}}-\text { spectral peak period }\end{array}$ & & \\
\hline
\end{tabular}

\subsubsection{Development of calculation model}

As already mentioned, the modal area is discretised by the triangular finite element grid. The size of the grid depends on the local wavelength $\lambda$ [11]. The minimum finite element grid resolution requires $8-10$ points per wavelength $[3,5,13]$. As the discussed port area occupies an approximate area of 146.000 $\mathrm{m}^{2}$, it is necessary to select the most appropriate minimum finite element so that the time of analysis can be considered acceptable. The triangular element with the side length of about $2.0 \mathrm{~m}$ was selected, and the grid with approximately 60,000 finite elements and 36,000 nodes was generated (Figure 5).

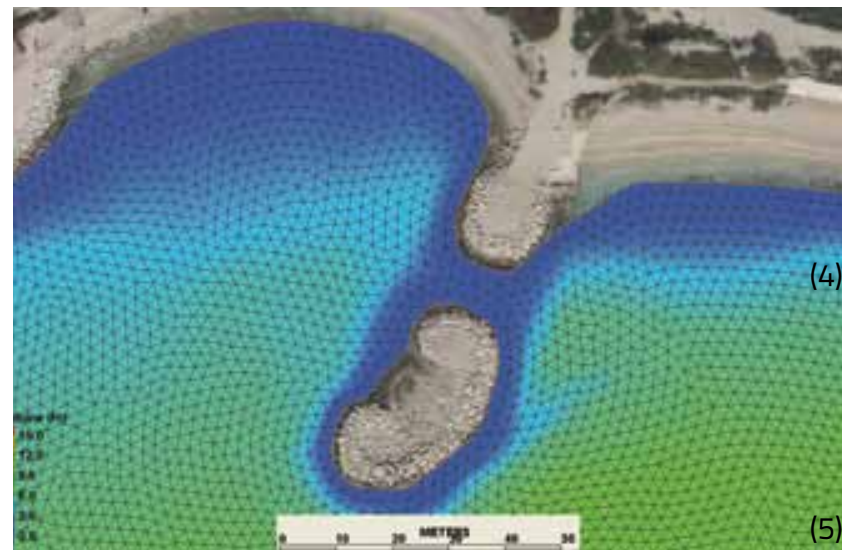

Figure 5. Finite element grid details

\subsubsection{Boundary conditions}

\section{Coastal boundary conditions}

The boundary condition for coastal line is written in general form as [3]:

$\frac{d \phi}{d n}=i k \frac{1-K_{r}}{1+K_{r}} \phi$

Where $K_{r}$ is the coastal reflection coefficient (between 0 and 1), and $n$ is the normal to the coastal edge. The boundary condition (4) for a finite element (Figure 6) on the coastal edge is written as follows $[5,13]$ : $\frac{\partial \phi}{\partial x_{n}}=i k \cos \delta_{i} \frac{1-K_{r}}{1+K_{r}} \phi ; \frac{\partial \phi}{\partial x_{s}}=i k \sin \delta_{i} \phi$

Where $x_{n}$ and $x_{s}$ are coordinates of this local system, and $\delta_{i}$ is the angle of an incident wave to the coastal edge obtained by iteration [5, 13] (Figure 6).

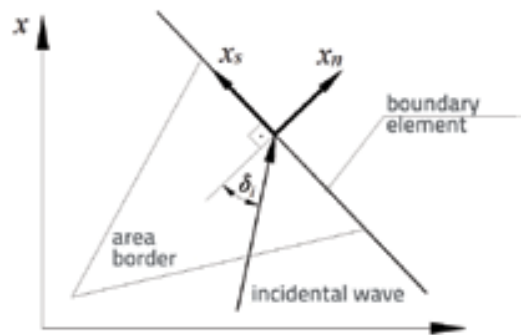

Figure 6. Boundary element and an incident wavelwith respect to the edge

The existing condition of the coastal line, and new solutions for the Hotel Split beach coastal line, consist of just a few typical coastal profiles, which contribute to the complexity of wave field deformations in the direct water area with their reflective characteristics. Related reflection coefficients (Figure 7) were obtained from literature $[11,12,13,14]$.

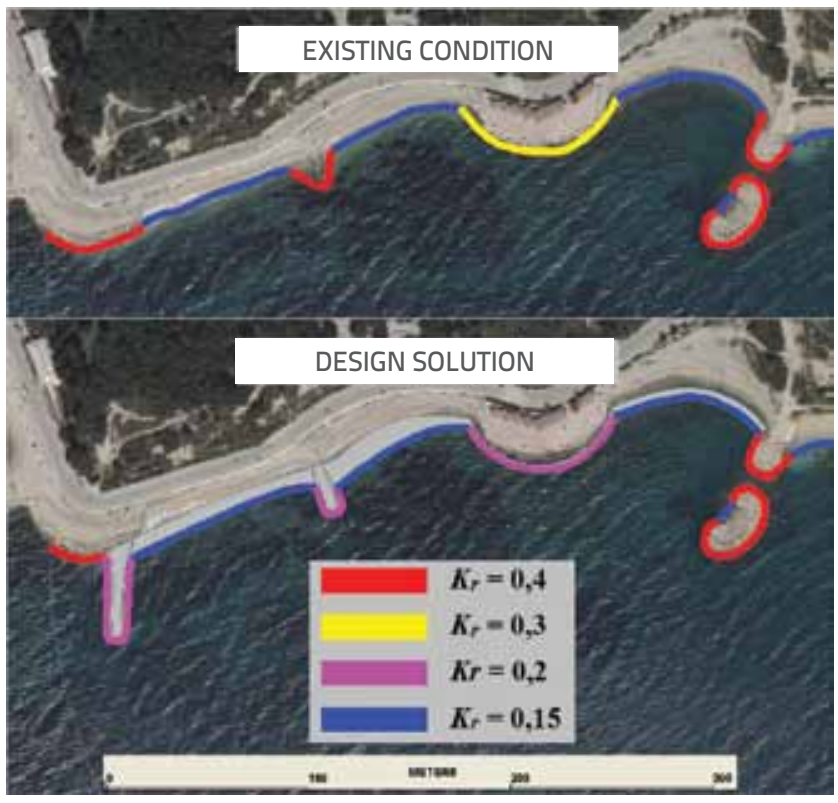

Figure 7. Coastal reflection coefficients per sections, for the existing condition and the final design solution

\section{Open boundary conditions}

Before defining this boundary condition, it should be noted that in the CGWAVE numerical model the open boundary is a semicircle because of the Sommerfeld radiation condition [11]. In simpler terms, all the waves that enter the model area through an open border, and then scatter due to obstacles in the waters of the model, have to leak back through the open 
border. The total two-dimensional complex potential $\phi(x, y)$ along an open border can be expressed as:

$\phi=\phi^{1}+\phi^{r}+\phi^{s}$

$\phi^{I}$ ncident wave potential, $\phi^{r}$ reflected wave potential, and $\phi^{s}$ scattered wave potential. Further parsing and simplifications $[1,3,13]$ give the total boundary condition for an open border:

$\frac{\partial \phi}{\partial x_{n}}=\left(i k-\frac{1}{2 R}\right)\left(\phi-\phi^{0}\right)+\frac{\partial \phi^{0}}{\partial x_{n}}$

Where $x_{n}$ is the local system coordinate along the open boundary, placed perpendicular to the tangent of the circle segment, and $R$ is the radius of a circle. Since an open border represents the line of incident wave generation, incident wave conditions have to be defined by the deep water wave power spectrum at an open border. The JONSWAP [13] was selected as the frequency range for numerical water area simulations, with different parameters for Jugo (SE) and Maestral (WSW) directions (Table 1), and directional dispersion around the main direction of incident waves.

\section{Analysis of the wave modelling results}

A series of numerical simulations of wave agitation was conducted in the water area with one sea level (MSL) and with two incident wave directions (SE and WSW). However, results presented in this paper are only related to the existing state, and to the final design solution for the Hotel Split beach [4].

Different parameters important for the beach morphodynamics and evaluation of its sustainability can be obtained through wave agitation modelling $[2,3,10]$. An important parameter is the wave height $H_{s}$ which indicates the potential quantity of energy that is brought to the coast by wave action. Furthermore, significant parameters also include the horizontal orbital velocity of wave particles at the bottom $u_{d}$ (orbital velocity at the bottom), and the wave power (coastal wave energy flow) $P_{i}$ : Both parameters are used to estimate the size and direction of potential transport of beach material caused by wave-induced flow $[5,15]$. Dominant coastal currents due to waves point to the biggest sediment transport in the area of wave refraction [15], which is a very interesting phenomenon [10, 11]. The following condition is applied for determination of the wave breaking line, [10]:

$H_{s b}=0,76 \cdot d_{b}$

where $H_{s b}$ i $d_{b}$ represent significant wave height and depth values at the wave breaking point. Two linear control lines have been determined for the case of the beach under study. These lines are valid for all cases of incident waves for the existing state and the design state (Figure 8).

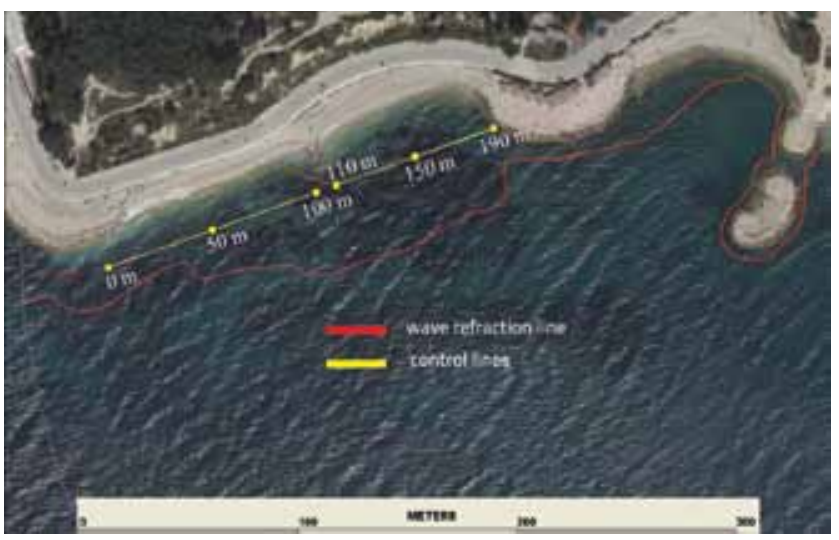

Figure 8. Wave breaking line for the existing beach state, SE direction of incident waves and selected control lines

Wave height $H_{s b}$ at the wave breaking point is directly related to the wave power $[10,15]$ :

$P_{1}=\frac{\rho g}{16} H_{s b}^{2} C_{g b} \sin 2 \alpha_{b}$

Where $C_{g b}$ is the local group wave velocity and $\alpha_{b}$ is the angle between the wave direction, and the bottom slope direction at the wave breaking point. Based on the wave strength $P$, data, it is possible to determine the amount of its potential volumetric transport along the coast $Q,[11]$. Since we have no data on the particle size distribution of beach materials for the considered beach, only the data on the wave power $P$, are presented, in order to detect beach parts with possible beach material transport problems.

Numerical wave agitation modelling results are presented as fields of significant wave heights $H_{s}$ with incident wave vector directions marked in the corresponding figures (Figures 9 to 12), and with vectors of total orbital velocities at the bottom $u_{d}$ and their vectors (Figures 13 to 16). Lastly, variations of $H_{s}$ and $P_{\text {, in control lines are }}$ shown in Figures 17 and 18.

The results show that waves from the SE direction have a much greater impact on the beach than waves from the WSW direction. Results concerning the existing state present parts of coast with possible beach material transport problems (bringing and removal), and are reflected in increased values of orbital velocities at the bottom $u_{d}$ for the SE incident direction (Figure 13) and wave power (Figure 18). Orbital velocities at the bottom are $u_{d}$ highest at the central part of the beach where they reach values of $1,30 \mathrm{~m} / \mathrm{s}$ (Figure 13), and the wave power $P_{\text {, }}$ is most prominent at the westernmost part of the beach within the first 20 meters of the control line, with the maximum value of approximately $5 \times 103 \mathrm{~N} / \mathrm{s}$ (Figure 18).

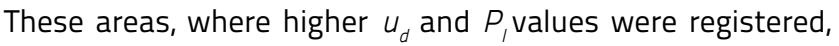
are also the most exposed parts of the actual field state. Certain interventions are needed in these areas in order to 


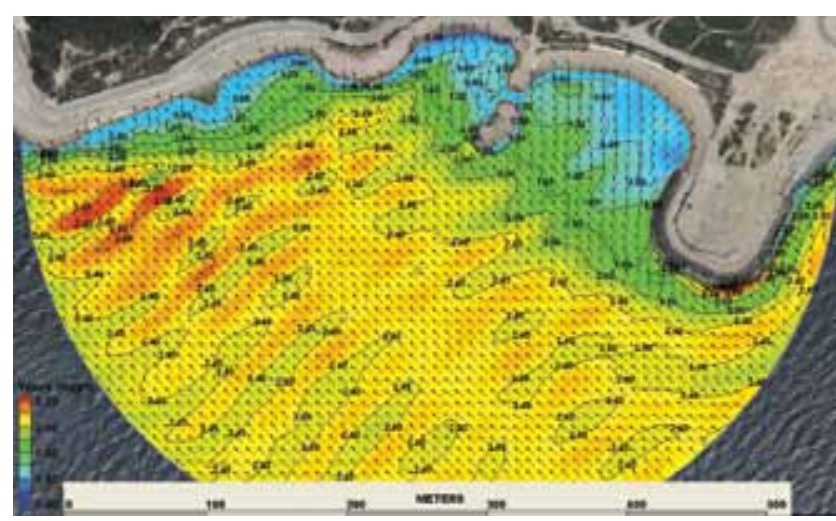

Figure $9 . \mathrm{H}_{\mathrm{s}}$ field and velocity vectors for the existing situation (SE)

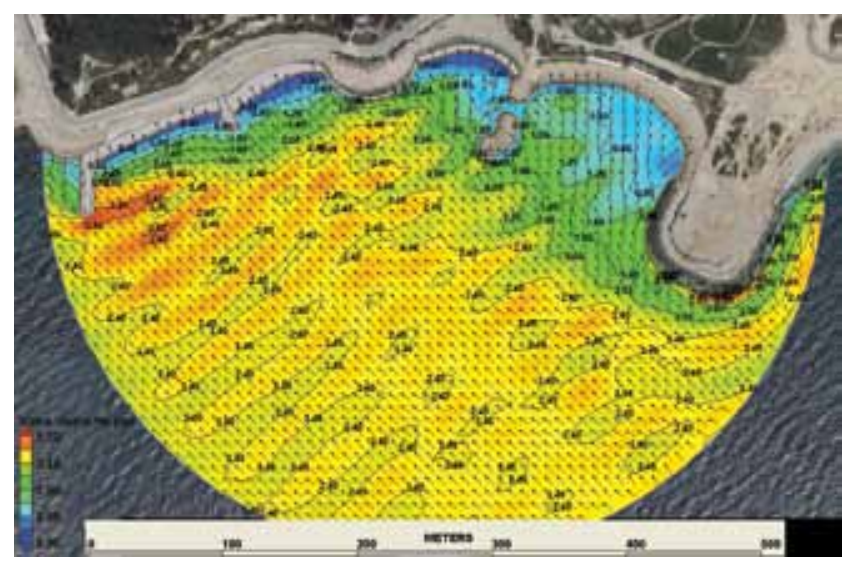

Figure 10. $\mathrm{H}_{\mathrm{s}}$ field and velocity vectors for the final project design (SE)

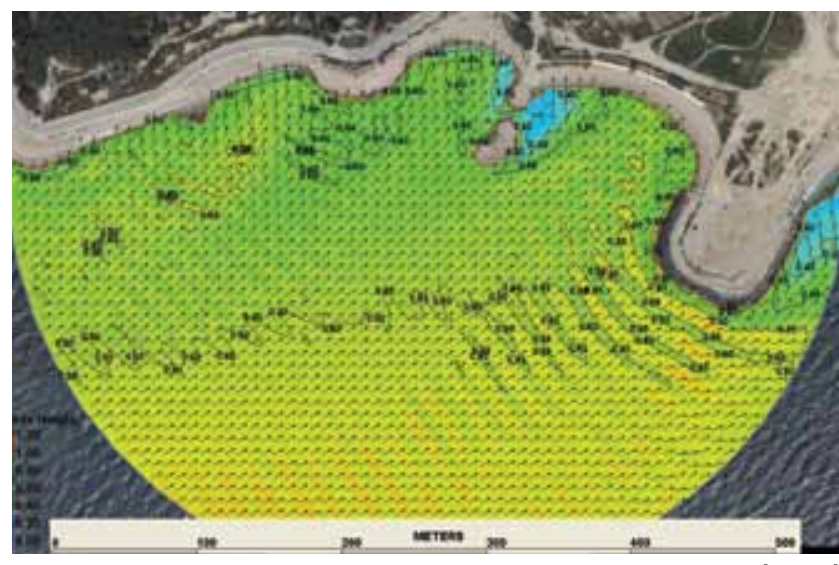

Figure $11 . \mathrm{H}_{\mathrm{s}}$ field and velocity vectors for the existing situation (WSW)

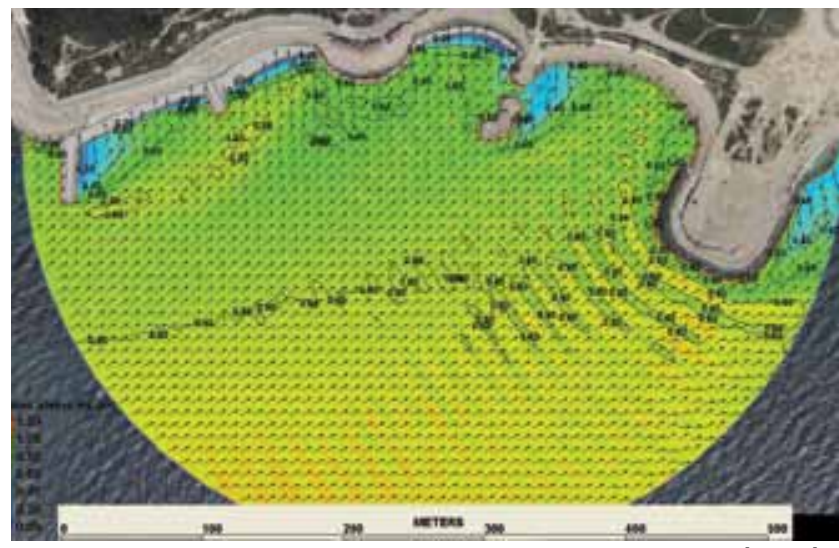

Figure 12. $\mathrm{H}_{\mathrm{s}}$ field and velocity vectors for the final project design (WSW)

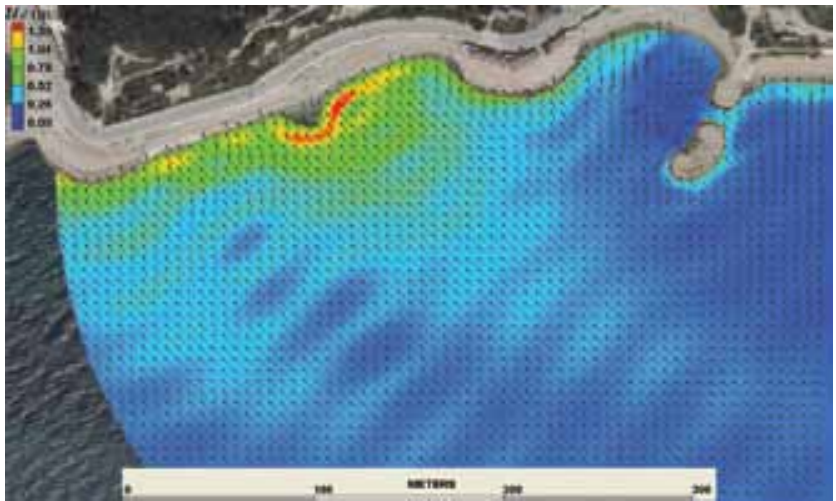

Figure 13. $u_{d}$ field and velocity vectors for the existing situation (SE)

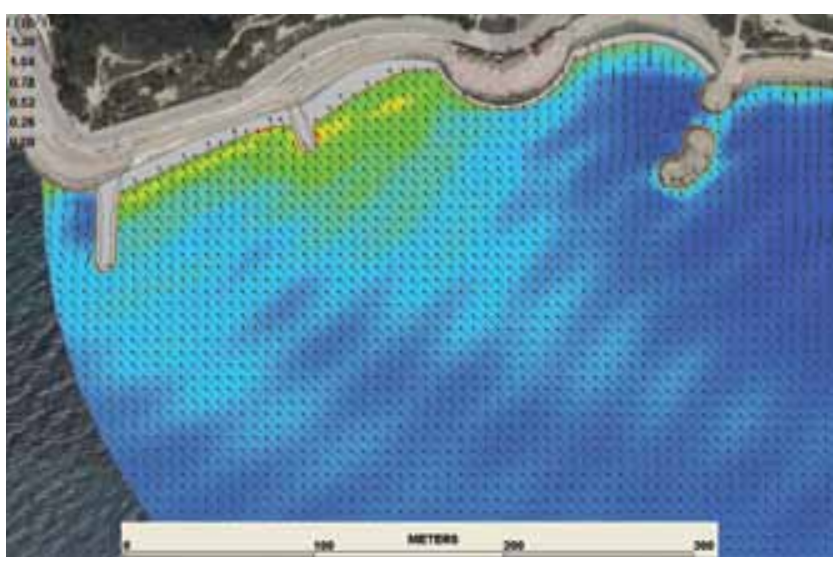

Figure 14. $u_{d}$ field and velocity vectors for the final project design (SE)

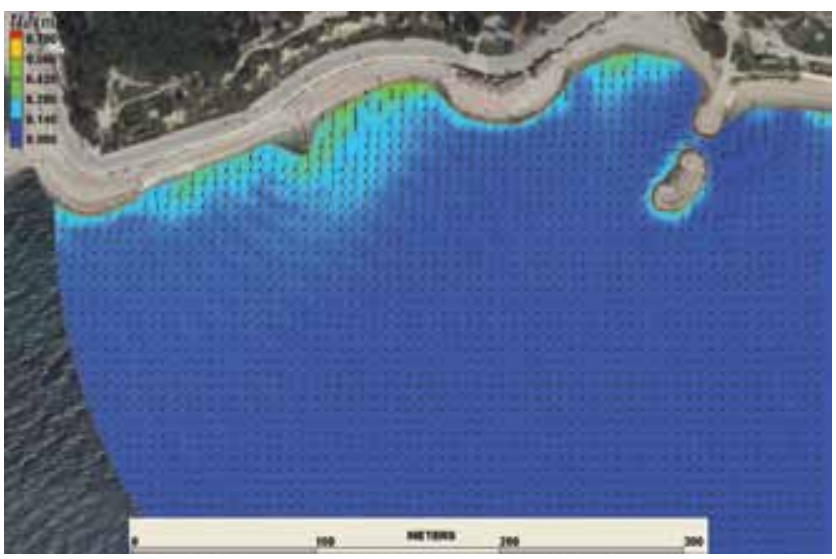

Figure 15. $\mathrm{u}_{\mathrm{d}}$ field and velocity vectors for the existing situation (WSW)

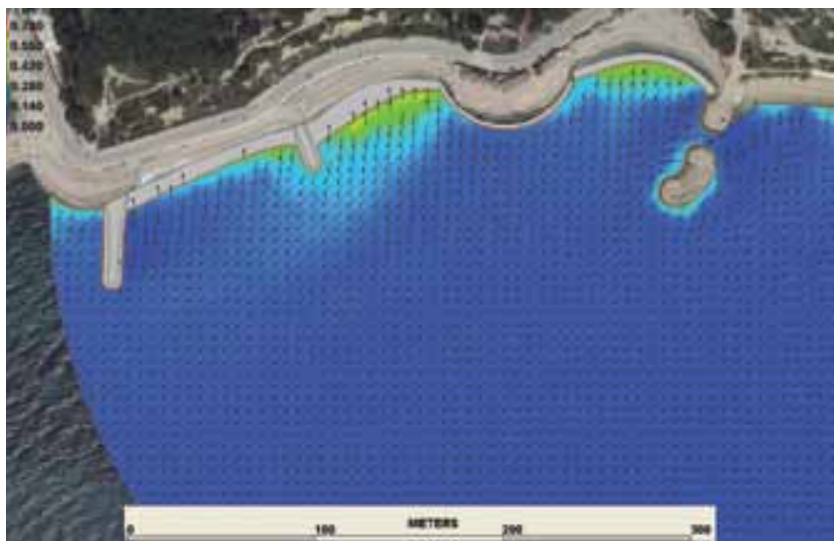

Figure 16. $u_{d}$ field and velocity vectors for the final project design (WSW) 


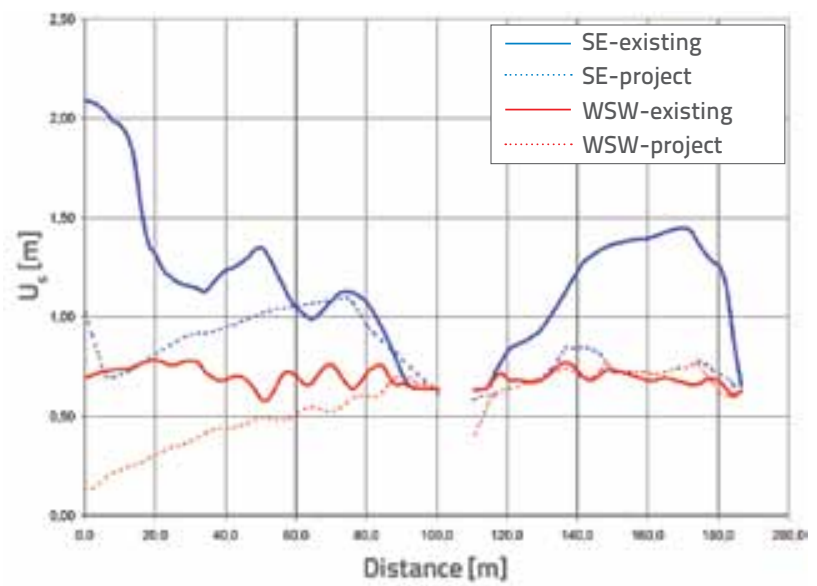

Figure 17. Variation of $\mathrm{H}_{\mathrm{s}}$ for the current situation and the final beach design solution, and for both incidental wave directions

reduce beach material sedimentation over time, and thus to increase sustainability of the beach.

At the same time, proper measures must be taken during these interventions to avoid worsening of the wave field condition in the waters concerned. It is evident from the final design solution that the fields of wave heights $H_{s}$ are very similar to the existing situation fields, and this in both incidental wave directions (Figures 9 to 12). However, significant wave height differences were registered within the area of wave refraction near interventions, which is especially evident at the control lines (Figure 17). Wave heights for WSW direction in the final project design are up to 3.5 times smaller than the existing wave heights, while they are up to 2 times smaller for the SE direction (Figure 17).

This is because new parts of the coast are planned with relatively low reflection coefficients (Figure 7), which affects all wave fields in the area of wave refraction. As for orbital velocities at the bottom $u_{d}$ for the final design solution, it is evident that values for the dominant SE direction in the entire beach area have been significantly reduced (Figure 14). Orbital velocity decrease at the bottom of the western and central parts of the beach can be noticed for incidental WSW direction, while the values at the eastern part have slightly increased, but with better vector direction. Wave power $P$, with highest values at the western part of the existing beach for incidental SE direction, has decreased significantly due to interventions (Figure 18). Wave power for the WSW direction has remained at approximately the same level for the final design solution as for the existing situation (Figure 18).

\section{Analysis of technical solution}

Very good and stable gravel beach has been obtained on the basis of many years of observation and study of wave action at the coastline of the hotel Split beach, and based on results obtained by this numerical model. The shore coarseness was defined according to literature [8]. The crushed stone from nearby

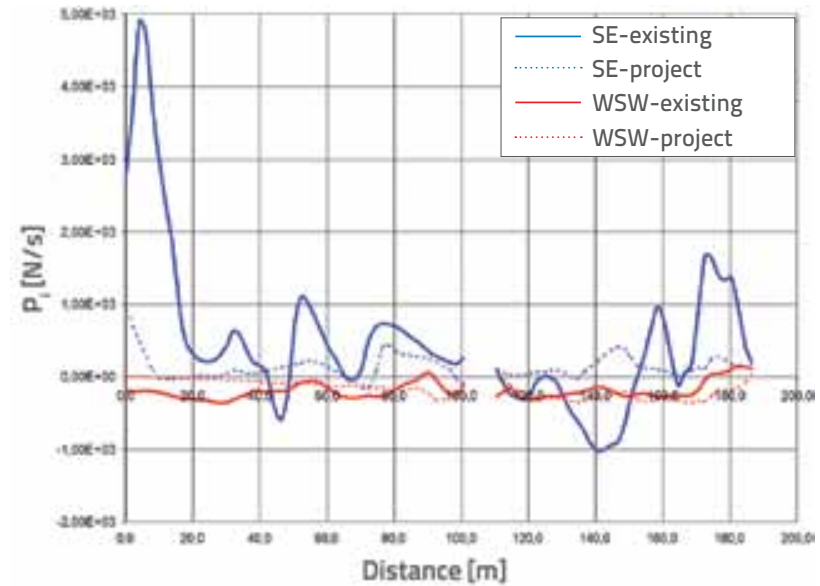

Figure 18. Variation of $P_{1}$ for the current situation and the final beach design solution, and for both incidental wave directions

limestone quarries was used. Sharp edges of grains were ground in just one winter season, and rounded pebbles were produced. As the beach was recharged with stone material in 2010, just before the bathing season, the Sava gravels in a layer of about $10 \mathrm{~cm}$ in thickness were spread on the surface and at the beach face. During the winter season of 2010/11 the shoreline was fully mixed and fully rounded. Currently an average grain size measures $d_{50}=32 \mathrm{~mm}$ in diameter. Shore conditions in the winter and summer are shown in Figures 19 to 22.

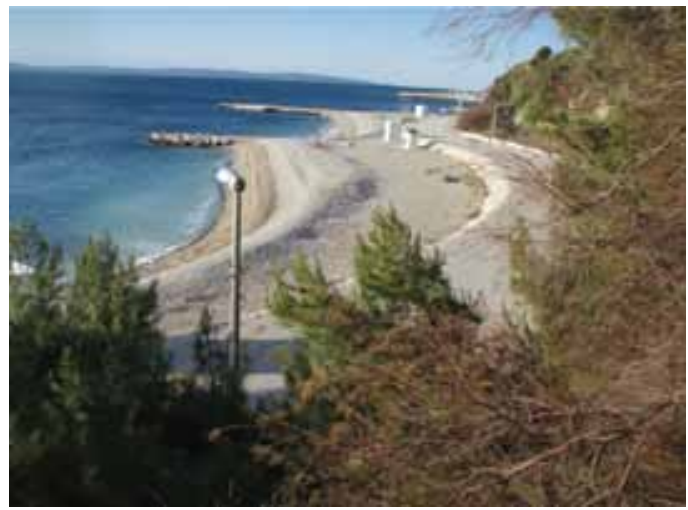

Figure 19. Beach condition in January 2011

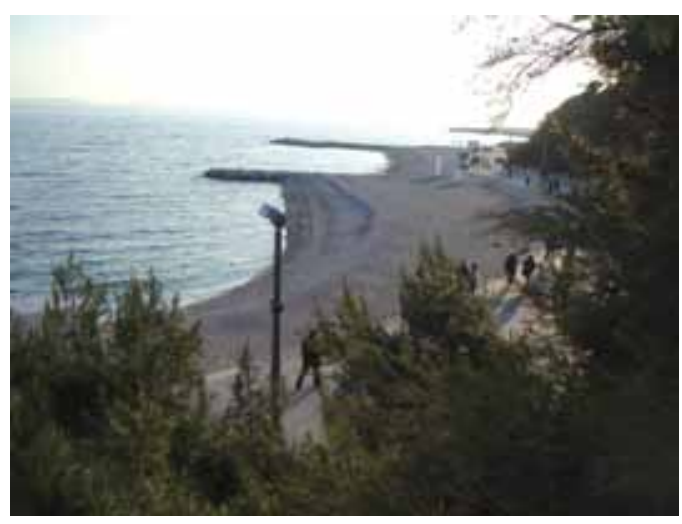

Figure 20. Beach condition in March 2011 


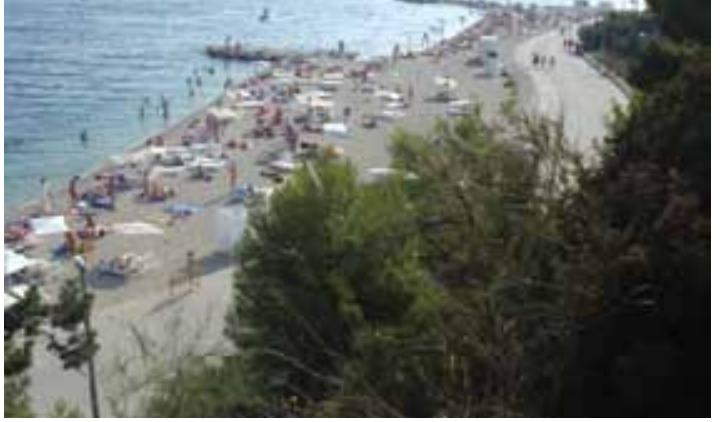

Figure 21. Beach condition in August 2011

\section{Conclusion}

The shape of beach with granular materials can be optimized in order to ensure its sustainability by means of a detailed numerical wave agitation modelling. At the same time, it is essential to have good knowledge of specific wind-wave conditions in the area under study. The numerical wave agitation modelling produces a set of parameters that are highly significant for the morphodynamics and sustainability

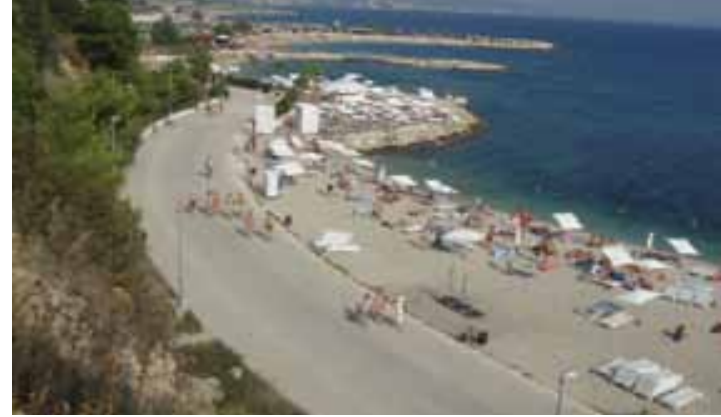

Figure 22. Beach condition in August 2011 (detailed view)

of the beach. These parameters are the wave height $H_{s^{\prime}}$ the orbital velocity at the bottom $u_{d^{\prime}}$ and the wave power $P_{\text {, }}$ An optimized form of the beach obtained through implementation of this procedure constitutes a sound basis for a detailed elaboration of other beach-development projects.

The analysis of the final design solution for the Hotel Split beach has resulted in a wide array of morphodynamic and hydrodynamic improvements of local waters, which has significantly advanced the sustainability of this beach.

\section{REFRENCES}

[1] Berkhoff J.C.W.: Computation of combined refraction-diffraction, Proceedings 13th Int. Conf. Coastal Eng., ASCE, Vancouver, 471490, 1972

[2] Berkhoff J.C.W.: Mathematical model for simple harmonic linear water waves. Wave refraction and diffraction, Publication no.163, Delft Hydraulics Laboratory, the Netherlands, 1976

[3] Fumin X. et al, Effects of storm waves on rapid deposition of sediment in the Yangtze Estury channel, Water Science and Engineering - Vol. 1, No. 1, 27-36, 2008.

[4] Booij N.: Gravity Waves on Water with Non-uniform Depth \& Current, Ph.D.thesis, Technical Univ of Delft, the Netherands, 1981.

[5] Demirbilek Z., Panchang V.G.: CGWAVE: A Coastal Surface Water Wave Model of the Mild Slope Equation, Technical Report CHL98-26, US Army Corps of Engineers Waterways Experiment Station, Vicksburg, Mississippi, 39, 180, 1998

[6] Panchang V.G., Wei G., Pearce B.R.: Solution to the Mild-Slope Wave Problem by Iteration, Applied Ocean Research, 13(4), 187199, 1991.

[7] Zhang J.: Incorporating Rubble Mound Jetties in Elliptic Harbor Wave Models, Graduate Studies of Texas A\&M University, 2007.

[8] Dean R.G., Dalrymple R. A.: Coastal Processes with Engineering Applications, Cambridge University Press 2004.

[9] Hrvatski hidrografski institut-Split, Stanje morskih struja i razi mora u Gradskoj luci Split, 2008

[10] Državni hidrometeorološki zavod Republike Hrvatske, Vjetrovalna klima za razdoblje 1966.-2005., Zagreb, 2006

[11] U.S.Army Corps of Engineers, CEM (Coastal Engineering Manual), 2003.

[12] Goda Y.: Random Seas and Design of Maritime Structures, Advanced Series on Ocean Engineering - Volume 15, World Scientific, 2000

[13] Chen W., Panchang V.; Demirbilek Z.: On the modeling of wavecurrent interaction using the elliptic mild-slope wave equation, Ocean Engineering 32, 2135-2164, 2005

[14] Thompson E.F., Chen H.S., Hadley L.L.: Validation of Numerical Model for Wind Waves and Swell in Harbors, Journal of Waterway, Port, Coastal and Ocean Engineering, 122, 5, 245-257, 1996

[15] Sorensen R.M.: Basic Coastal Engineering, Third Edition, Springer, 2006 